\title{
The Interaction of City and Water in the Yangtze River Delta, a Natural/Artificial Comparison with Euro Delta
}

\author{
Yan Wang ${ }^{1,2, *}$, Wei Dong ${ }^{1}$ and Luuk Boelens ${ }^{2}$ \\ 1 School of Architecture, Southeast University, 2 Sipailou, Nanjing 210096, China; dongwx@163.com \\ 2 Center for Mobility and Spatial Planning, Ghent University, Sint-Pietersnieuwstraat 41 B2-1, \\ B-9000 Ghent, Belgium; Luuk.Boelens@UGent.be \\ * Correspondence: yan.linda.wang@hotmail.com or Yan.Wang@UGent.be; Tel.: +86-25-8379-4579
}

Received: 20 September 2017; Accepted: 18 December 2017; Published: 8 January 2018

\begin{abstract}
Metropolitan deltas have much in common because of similar urban water management conditions. This paper will introduce the interaction of urban development and water management in and around the Yangtze River Delta from a historical perspective. It will compare the Yangtze River Delta with a short overview of the historic water urban developments in the Euro Delta. This paper will explore the importance of the variations of both delta areas, especially regarding the similarities and differences in urban morphology and delta governance. In conclusion, we will outline new challenges of resilient urban water management in both delta areas.
\end{abstract}

Keywords: water urban history; Yangtze River Delta; Euro Delta; urban morphology; delta governance

\section{Introduction}

The emergence of cities in world ancient civilizations is connected to large waterways. Civilizations needed water resources to settle down in one location, as rivers, lakes, and water pools were cradles for food. Canals and natural water streams were also used as defensive mechanisms. Later on, urban settlements prospered, as waterways allowed for trade and transport of goods and people, further spurring urban development [1]. Even more, the vast deltas of big rivers, with their numerous side branches and estuaries of sweet and salty waters, were incentives for massive urban developments [2]. In the long run, these deltas also served as gateways and turntables for inland and overseas trade networks. Despite enormous risks for storms, flooding, and even raids from enemies overseas, deltas had a special attraction for urban settlers. This was common in Western Europe, Asian China, and elsewhere.

The Yangtze River, for instance, is the mother river in central and southern China, and its delta is the oldest location where people settled. The Yangtze River Delta is a region whose urban settlements have prospered from ancient time to present day, especially the current massive metropolis in Jiangsu Province, Zhejiang Province, and Shanghai. It is one of the highest population density and immigrant areas in China, with numerous big cities that contribute to making it China's largest economic zone. It covers an area of 99,600 square kilometres (38,500 sq mi) and is home to over 115 million people [3]. As such, it could be compared to other metropolitan deltas, such as the Pearl River Delta, the Ganges or Padma Delta, the Nile Delta, the Congo Delta, and so on. However, historically, the urbanization of this Yangtze River Delta area has had specific characteristics. While the urbanization of other deltas traditionally followed natural features like evolving riverbeds and/or the defence against floods, the ancient urban history of the Yangtze River Delta was less focused on defence mechanisms, but rather on vast man-made water constructions. The Chinese Grand Canal, for example, was created 
by the ancient Chinese labouring people 2500 years ago, and was later on added to, improved upon, and perfected by several emperors over the course of more than twenty centuries. It is the longest, largest, and one of the oldest of the world canals, linking up five main rivers in Eastern China (Hai River, Huang River, Huai River, Yangtze River, and Qiantang River), and two main metropolitan delta areas. As such, the Grand Canal was ancient China's principal line of communication, occupying a significant position in the process of urban development [4].

At present, China's urbanization has exceeded the threshold of $50 \%$, toward a more rational and sustainable development. In the key moment of urbanization transformation, under the international background of ecological resources and interests, with the China sustainable strategy of "New Urbanization" and "Chinese Dream", "water and city" is of great historical value and realistic significance. More and more scholars have pointed out that in order to cope with climate change and water environment problems, and restore the adaptability of the ancient urban agglomeration to the water system, the "resilient development" of urban social culture is particularly important.

This paper will focus on building the pattern of urban changes along the main water network, while at the same time, use the theory of urban morphology, based on the regional level, from the time dimension of "historical evolution-the current and future development and challenges". It takes a new look, with the perspective of "urban morphology-urban governance", at the interaction of water and city, revealing the elements and characteristics of the historical development and the internal motivation and regularity of urban space development and evolution. Moreover, the paper will compare the historical urban governance, the development of politics, economy and culture of China's Grand Canal and Yangtze River Delta, and the European Low Countries' waterfront cities and economic elements in the waterfront city formation, and the significance and value of the development process. It studies the nexus and connection of the city water network pattern and social and economic changes, and the significance and value of social, cultural, and economic factors in the formation and development of waterfront city. There should be something in common in delta metropolitan, according to the historical reviews of the urban development, the paper will point out the similarity of delta's urban agglomeration. Due to the different culture, there should be some differences in urban governance. Going forwards, the delta metropolitans could learn from each other to cope with the challenges that urban adaptability and sustainability.

In this paper, we will explore how this structure has influenced urban development within the Yangtze Delta, in contrast to the more "natural" urban developments with the metropolitan deltas of the Rhine, Meuse, and Scheldt, the so-called Euro Delta [5]. Although each of these regions is structured according to particular sociocultural and institutional mechanisms, we will explore the specific interplay between water and urban infrastructure in these deltas. Moreover, we will also explore the differences within the urban mentality, or DNA ("DNA profile of cities": this is the highly dynamic, but also somewhat situational, path-dependent way people and space interact, determined by the geographical and institutional preferences of politicians, entrepreneurs and citizens over time) [5], of both deltas, according to relational ethnographic research, which is already introduced in the Euro Delta area [2].

Three perspectives will be adopted in the methodology. First, at an urban morphology level, we will discuss the distribution of the waterway systems and urban development in time and space. Here, the paper will take the social, economic, and cultural features of metropolitan deltas, with historic analyses of the water and city interaction and morphological transitions. We will identify typical cities in the distinguished periods to discover the impact of water on urbanization. The paper is committed to the study of historical urban spatial context, emphasizing the importance of remapping of historical cities to extract valuable historical information, and promoting planning and design techniques to achieve the integration of historical space and the overall protection of the historical environment. Through the remapping, various information is collected and edited into the database.

Second, from a delta governance perspective, we will research the inner motives and mechanisms of both deltas' areas (e.g., the factors, actors, and institutions of influence for the specific delta 
urbanism). Urban morphology is the embodiment of urban governance on the material level, and urban governance is the internal dynamic mechanism of urban morphology. Urban governance is the outcome or mediating element in actor-factor-institution interaction, and affects the generation, prosperity, and development of the city. This dynamic mechanism is natural, geographical, internal, and external. Urban governance involves different decision makers, different influencing factors, and is also affected by different institutional rules. Shown in each different period, urban morphology will be affected and determined by these three factors (actor, factor, institution), as the city gene exists in the urban evolution process. Actors, factors, and institutions in specific spatiotemporal situations (re)constitute each other in their surroundings [6]. These three elements interact and interplay with each other.

Finally, through the horizontal comparison of different places in the same period, and the vertical comparison of the same places in different periods, the main characteristics of historical information and spatial pattern and the causes of change are discovered, and we will conduct a preliminary comparison of two main metropolitan deltas with respect to urban morphology and delta governance. The regulation of the urban siting, the characteristics of the cities' distribution, and the specifics of their development, will be used to compare urban morphology. We will present short historical morphological overviews of each delta, in order to explain the similarities and differences between them.

\section{Yangtze River Delta in Space and Time}

From the definition of the delta, the real Yangtze River Delta is situated south of Jiangsu Province and present-day Shanghai. The urban history of this delta is not only characterized by human defence against regular flooding and/or changing river mouths, but can also more specifically be presented in seven spatio-cultural stage characteristics, in regard to water-city interaction. From prehistory to the modern time, each of these stages has contributed to specific urban features, due to various motivations.

\subsection{Early Physical Geography and Settlement Development $(<4000$ BC)}

The first traces of urban settlements in the Yangtze River Delta date back to ancient times. In one area, more than 20 traces of urban developments in the Palaeolithic age $(<8000 \mathrm{BC})$ have been found. The findings multiply to around 300 traces in Neolithic age (8000 BC-4000 BC). At the time, the lower reaches of Yangtze River were rice-growing areas, establishing the earliest Chinese rice agriculture. For the Majiabang Culture Period (5000 BC-4000 BC) rice relics were found in Suzhou. This represents the earliest irrigation systems of rice paddies in Chinese history, suggesting that the middle and lower reaches of the Yangtze River regions were important cultivated rice origins for China and the world. This could be due to three possible reasons [7]. First, in the beginning and middle of the Neolithic age, around the Taihu Lake Plain, which is a warm, wet climate in a moist environment, the stable source of water and large open flat land were conducive to the growth of rice. Second, the growth of the population demanded a sufficient food supply. The more stable rice cultivation was an important complement when compared to the unpredictable sources of hunting and fishing. Third, the technological inventions of diversified stone and wooden tools and the construction of water irrigation systems, such as water wells and other facilities, promoted the development of rice agriculture. Many settlements gradually formed several cultural groups, which created the conditions for the formation of the early city (Figure 1). 


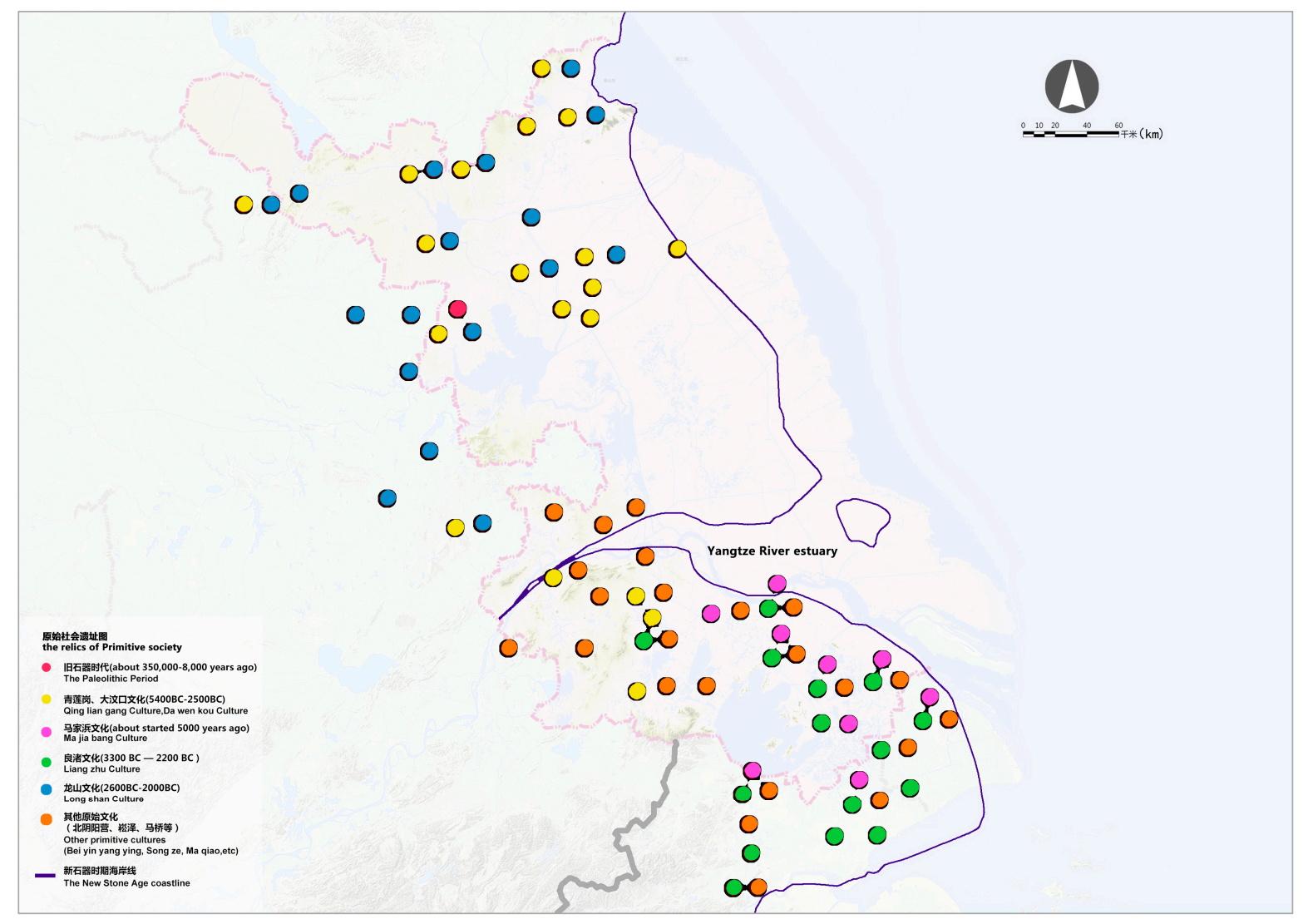

Figure 1. The relics of primitive society in the Yangtze River Delta.

\subsection{The Formation of the City $(<-200$ BC)}

The first urban formations were built upon these relics. They were mainly political in nature. In the delta area of the Yangtze River, with the accumulation of rice cultivation and material wealth, "Wu" became a major vassal state during the Spring and Autumn Period (770 BC-476 BC). Wu claimed its hegemony over the Central Plain and other states. Thus, a water army in urban strongholds, and quick and reliable water transport in between became fundamentals needed in the Wu state. In $486 \mathrm{BC}$, the king of Wu dug the so-called Han canal, linking the strongholds at the Yangtze River and the Huai River. It was the earliest artificial canal recorded in literature, and mainly served military purposes to compete with Central China governors. Moreover, the succeeding kings of Wu constructed many small canals, linking up not only the Yangtze and Huai Rivers, but also Taihu Lake, Qiantang River, the sea, and so on, with their own capital. The canals were mainly military: built to transport soldiers of war. During times of war, and even in peace, they were used to transport military food supplies, and opened up further north-to-south water trade. They also promoted the development of pre-mercantile cities in the surrounding areas. Many cities were distributed along the rivers, lakes, and main waterways. They became the main centres of rice production to guarantee food reserves and supplies for the armies of $\mathrm{Wu}$. The cities were regularly built with a general urban outline leaning against the hill and facing the river, with convenient transport services. This evolved into a specific cultural city pattern, which influenced the urban layout for more than a thousand years, as seen in present-day Nanjing, Zhenjiang, Changzhou, Wuxi, Suzhou, etc. In fact, it became the basic pattern of all present-day main cities in Jiangsu Province, and made Yangtze River Delta one of the cradles of Chinese urban civilization (Figure 2a). 


\subsection{The First Canal Urban System (250 BC-600 AD)}

The Qin and Han dynasties tried to re-establish the main economic zones and the core regions of Chinese social and urban development up north in the Yellow River Basin. However, between the 3rd and 6th centuries, the six successive vassal states ( $\mathrm{Wu}$, Eastern Jin, Liu Song, Southern Qi, Liang, and Chen) set their capitals in present-day Nanjing. Compared to northern China, which suffered from unceasing war and a recession of economy and culture, the societies of the so-called "Six (vassal) Dynasties" were relatively stable. This shifted the nation's economic centre of gravity towards the south, and promoted the progress of water management in the Yangtze River and Huai River regions. Great achievements were gained in science, technology, philosophy, and art in these areas, thus helping Jiangsu become the centre of China at the time.

Thus, the use of the canals shifted. While the canals originally served to transport soldiers and military food and supplies, the canals were now also used for irrigation and the opening up of wastelands. Since the first canals regularly dried up, due to the tides, changing weather, and seasons, the people started to build locks in the canals to store water, and to serve sweet water irrigation purposes all year. The canals then became navigable all year. The first lock was built in the Pogangdu canal, linking up Jiankang City (present-day Nanjing) with Suzhou and Shaoxin, strengthening the connection between the capital and the major economic zones around Taihu Lake. The eastern part of the canal (from Danyang to Suzhou and Shaoxin) was the origin of the Jiangnan Canal of the Sui dynasty [8]. Furthermore, small canals were constructed, like the Zhuyu Canal (present-day Tongyang Canal) and the Jiangdu New Canal (Zhengyang Canal) from Yangzhou to Yizheng. Because of the siltation of Sheyang Lake (the old Han Canal runs through it), the governor of Guangling (present-day Yangzhou) built a new waterway, directly from Gaoyou to Huai'an, reducing 300 miles of the boat ride. Suzhou became the most important urban connection point in this canal network, setting new urban canal and water standards, which were the stabilizing factors for Suzhou city's location. Three levels of water systems were presented in Suzhou. The first was an external moat and canals. The second was known as the "three horizontal and four vertical lines" river system in the ancient city. The third was the large number of inner tributaries of main rivers crossing through the city. This particular canal and water system made Suzhou well-connected with the thriving economy of the Central Plains' (comprising the middle and lower reaches of the Yellow River) (Figure 2b).

\subsection{Grand Canal Urban System (550 AD-950 AD)}

In the periods of the Wei, Jin, and Southern and Northern Dynasties (220 AD-589 AD), national unity and peace became the common aspiration of people of all nationalities. At the beginning of the unification of China in the Sui Dynasty, the economy had been restored and linked up to the Grand Canal, setting the stage for the prosperity in the Tang period. The Silk Road allowed economic and cultural exchanges between China and the regions in India, the Middle East and even Europe, making the Tang the number one power of the world in those days. Moreover, Jiangsu became the most important area for grain production in the Tang Dynasty, and the Grand Canal accelerated the shift of the economic centre of gravity from the north to the south. For instance, Yancheng and Taizhou became two major areas for salt production, and Yangzhou owned the most prosperous industries and commerce in China at the time (Qiu Lu, 855).

In this prosperous era, Emperor Sui Yang opened up Yongji canal, Tongji canal, Han canal, and Jiangnan canal, thereby completing the already-existing canal branches towards a so-called Grand Canal Route. Taking Yuhang (Hangzhou) as the departing point in the south, the canal flew through Jiangdu (Yangzhou) and Luoyang, to Zhuojun (Beijing) in the north, and connected five major rivers (Qiantang River, Yangtze River, Huai River, Huang River, and Hai River), thus becoming the main North-South traffic artery. Although the purpose of the canals was also militaristic, they served a catalytic role in the North-South economic and cultural exchanges, and strengthened national unity. Furthermore, they contributed to Jiangnan's economic development and enhanced Jiangnan's culture. New canal city archipelagos came into existence, as Chuzhou (Huai'an) and Hailing (Taizhou) 
developed into major commercial centres along the canal. Yangzhou grew up into the first metropolis in Southeastern China, and Pengcheng (Xuzhou) became the regional central city. This gave rise to a new urban model, which consisted of the Grand Canal and Urban Belt. Due to the North-South economics along and around the canals, multitudes of cities and towns emerged, linked by the canals and waterways, presenting a strip of distribution.

\subsection{Water Cities (900 AD-1400 AD)}

After the final unification in the Song Dynasty, the Yangtze River Delta witnessed a growth of urban population, an increase in social status, and the formation of the urban class, resulting in commercial prosperity and expansion of cities. In the NanSong Period, Yangzhou became a vital military region controlling the place between the Yangtze River and Huai River. Innovations in agriculture and the regulation of the water system supported a further growth in industrial production. The silk cotton industry production gradually became specialized, and was exported overseas. Suzhou and Jiangning became major handicraft and business centres, while Zhenjiang, located in the intersection of the Yangtze River and the Grand Canal, became the crossroad of North-South trade, transferring supplies, food, and articles between Taihu Lake and Qiantang River. In this period, the facing streets were usually shops with a residential yard at back. Because of their distinctive local feature, the urban landscape of Yangzhou and Suzhou played significant roles in the history of China's urban development. During the Yuan Dynasty, Suzhou, Nanjing, and Songjiang became centres for silk and cotton fabric manufacturing (Nanjing Museum).

Therefore, although the Yuan Dynasty set the government seat in Beijing, the economic centre stayed in the south. The transport links were the key to maintain political stability and economic development. The government took a series of measures to ensure the Grand Canal was navigable. For the governance of the Jiangnan canal alone, the government constructed 79 locks and water gates. The final Grand Canal system was formed, stretching over $1800 \mathrm{~km}$. It presented a distinct change as compared to former times. First, the main canals changed from East-West to North-South direction. Second, the dredging and constructing of canals used locks for water equilibrium.

The waterways remained the lifeblood of the city's economic development and people's lives in this area of China. The prominent regional urban landscape presented growing urban nodes in distinctive water networks, called water cities (Figure 2c).

\subsection{Diversification of Urban Development (1350 AD-1850 AD)}

During the Ming and Qing Dynasties, the economy of Jiangsu experienced unprecedented expansion and saw sprouts of capitalism. The booming economy sparked prosperity in technology, literature, and art. The architectural engineering and shipbuilding in Nanjing represented the top achievements of the time. Jiangsu was also a major supplier of handicrafts and exemplified the peak of the development of the Chinese feudal society in the Ming and Qing Dynasties. The canal system advanced the importance of the cities along the canal. From Yuan Dynasty to Qing Dynasty, Huai'an became a city with major administrative powers, with the seat of the governor of canal transportation on the Grand Canal.

At the time, the governor constructed many small canals and dams to make a water system with more efficiency than just one river in the foreland-inland trade. In the same way, the government did not rely on the prosperity of one city anymore; the promotion of massive cities rose along the new canals and lakes. The Ming and Qing Dynasties saw the rapid development of Jiangsu's cities and new towns. The structure of water and cities formed the axis of the Grand Canal, the Yangtze River, the ancient Yellow River, and the Huai River, for urban development. Each of the cities in the north, middle, and south of Jiangsu also presented distinctive features. In northern Jiangsu, most small canals were used to transport salt, linking up the sea and the main canal. Thus, the canal's direction changed from a North-South direction towards an East-West urban structure. In the middle, at the coastal areas, the cities were part of an overall sea defence system, while in southern Jiangsu, the cities 
evolved due to the dense water network. The existing water cities turned into separate water towns, and even seemingly water countries, presenting a more diversified development in the Yangtze Delta.

\subsection{The Rise of Railways and the Urban National Industry (1800 AD-1950 AD)}

Because of the change of transport (canal transport to sea transport) and the construction of the railways in the late Qing dynasty and at the beginning of the Minguo Period, the influence of the Grand Canal declined. As a result, the characteristics of cities' distribution shifted from the traditional focus on canals and rivers towards the railway line. Railway hub cities developed quickly, which enhanced the connection between people, goods, information, and so on, through new channels, including internationally. In the Yangtze Delta, this promoted the regional growth of the French, and later British, outposts in Shanghai. Before opening up its port, Shanghai was just a small town. But by the late 1920s, Shanghai's transport network was well-developed, and its urban area expanded by more than 10 times [9]. The Shanghai-Nanjing Railway promoted Shanghai as an international turntable of modern regional economic development, and enhanced the throughput of Shanghai and radiation ability. Furthermore, this newly built Shanghai-Nanjing railway line enhanced the position of Wuxi as an inland transit city for the goods imported from Shanghai. Wheat, rice, cereals, silk cocoons, cotton, and other goods, were collected in Wuxi, which became the commercial centre in southern Jiangsu. But the railways also had an impact on other cities in the area. Westernization and the development of the national bourgeoisie contributed to a batch of modern industrial and commercial cities along the river and in China's coastal areas. According to the "History of Chinese Modern Agricultural Information" statistics, from 1895 to 1913, Jiangsu Province housed more than 70 national industries, mostly established by Nantong national industrialists like Zhang Jian. In the early twentieth century, Zhang invested in numerous companies, including the workers' settlement nearby [10] (Figure 2d).

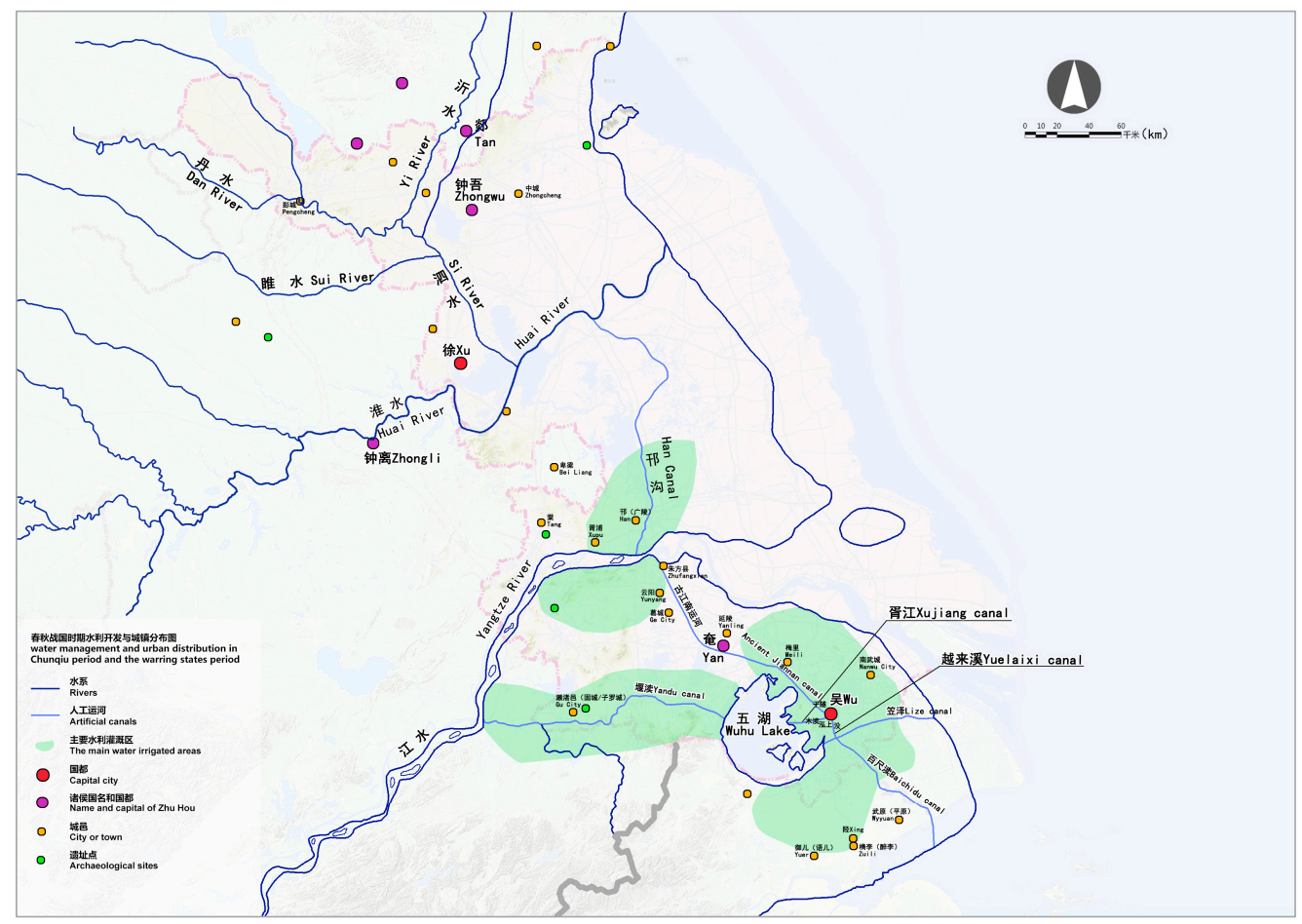

(a)

Figure 2. Cont. 


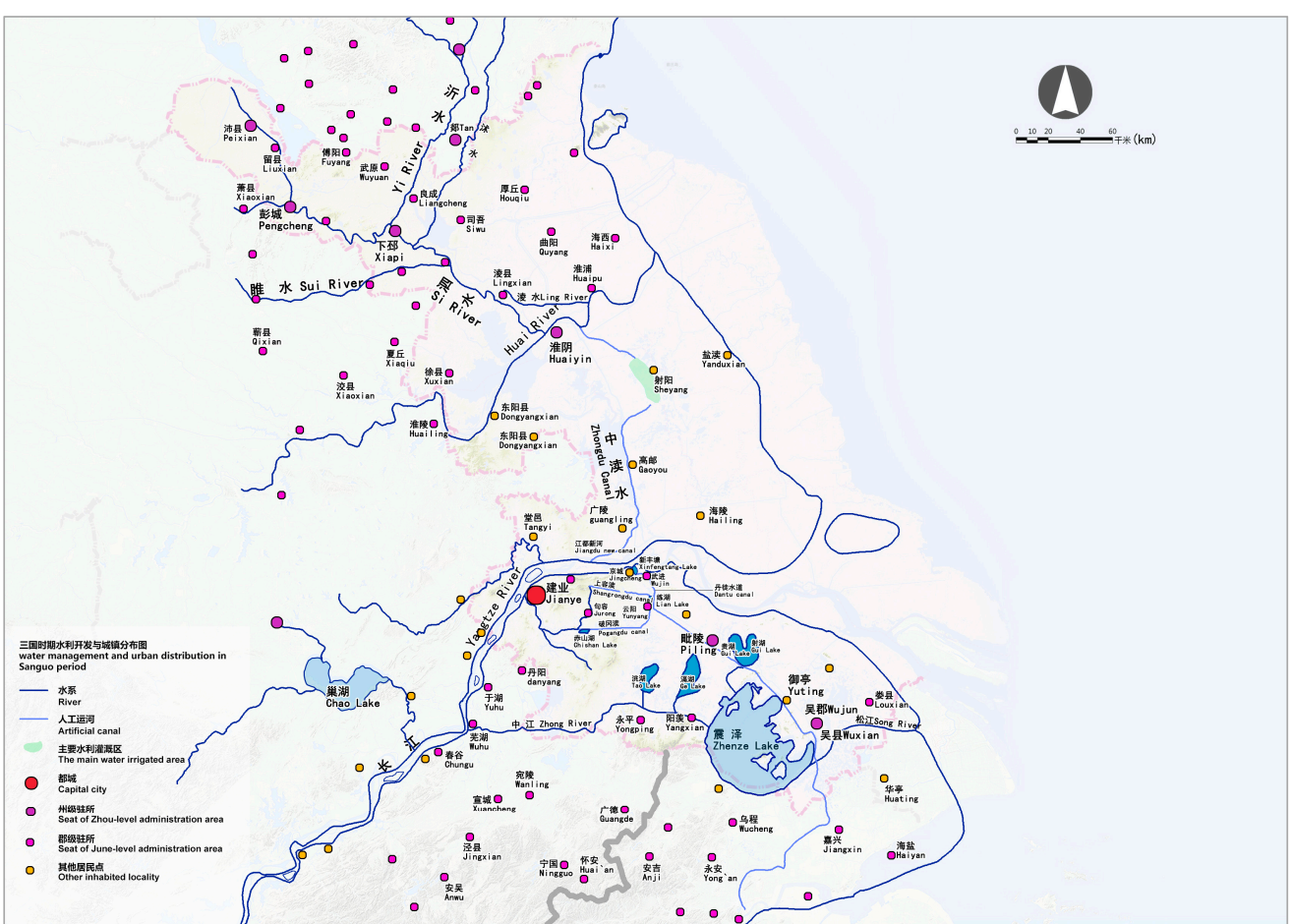

(b)

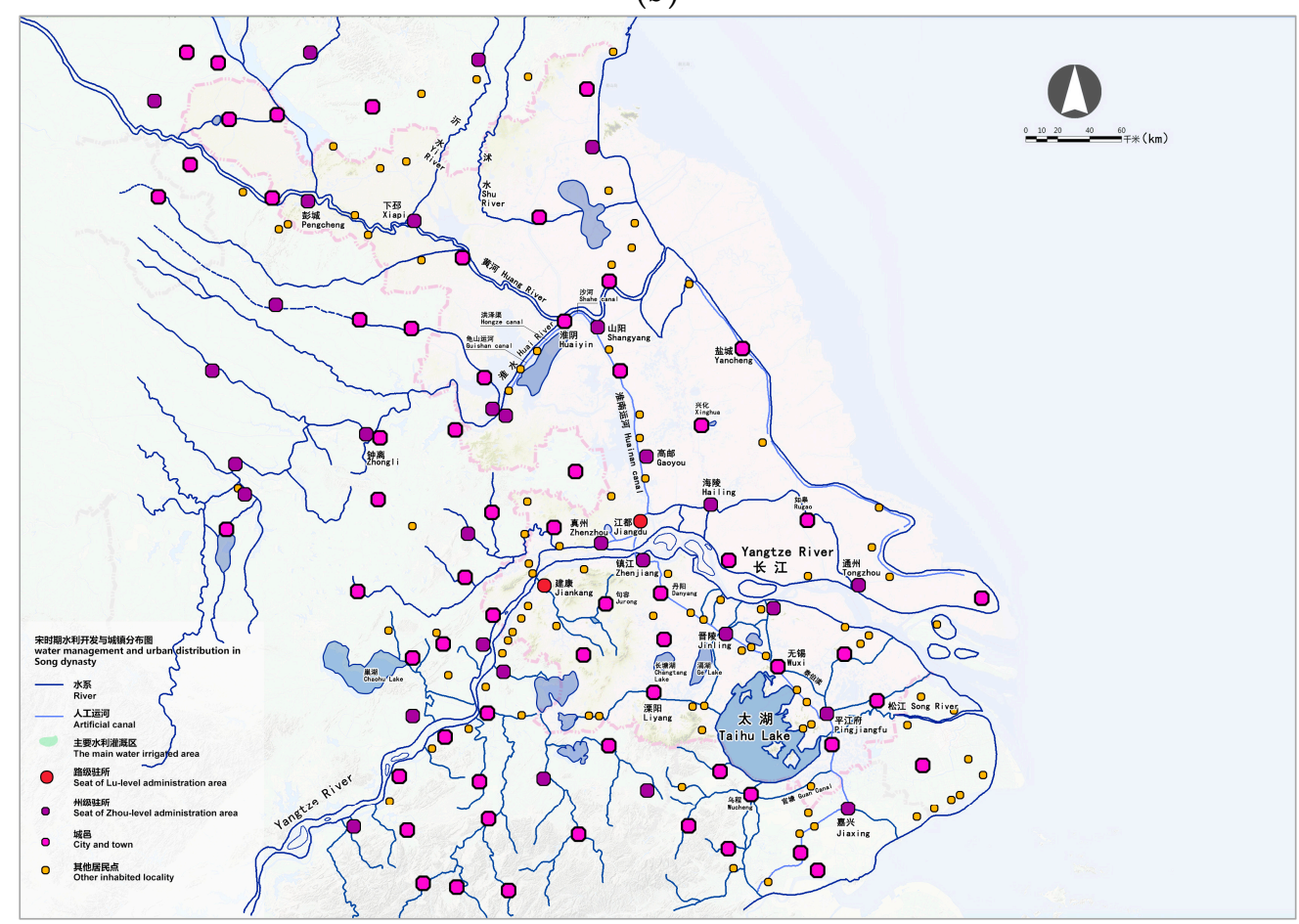

(c)

Figure 2. Cont. 


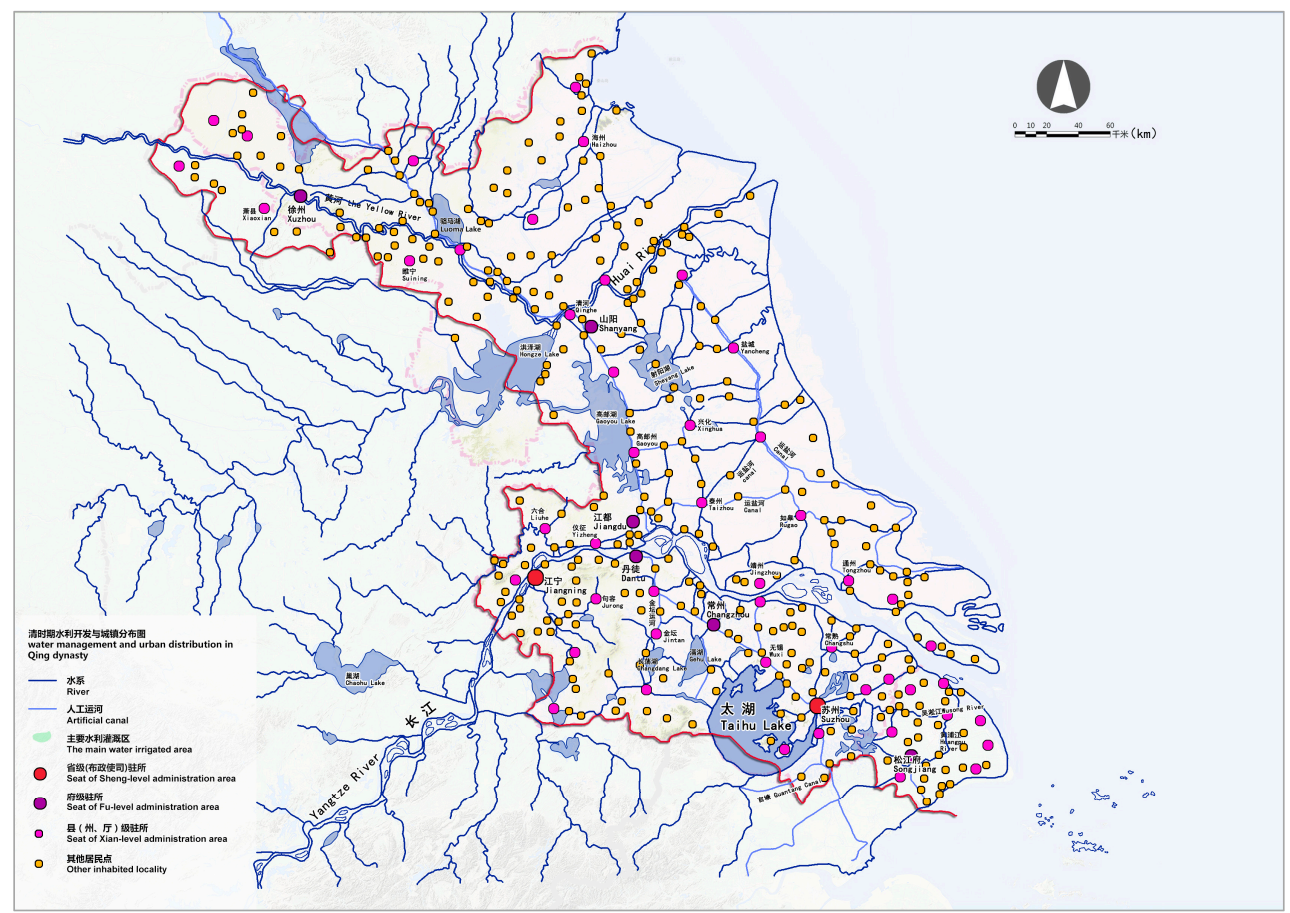

(d)

Figure 2. Water management and the urban morphology transformation of Yangtze River Delta. (a) Spring and Autumn and Warring States periods (770 BC-221 BC); (b) Six Dynasties (222-589 AD); (c) Song Dynasty (960-1279 AD); (d) Qing Dynasty (1636-1912 AD).

Throughout history, the interaction between water systems and cities within the Yangtze River Delta of Jiangsu Province mainly embodied four aspects:

1. It formed networks of cities and waterways, especially in three types: the urban archipelagos around Yangtze River and Taihu Lake, the city group along the Grand Canal, and the coastal cities group; first as military strongholds, and later as industrial and/or logistic turntables.

2. Although Jiangsu's cities and towns originated as military strongholds, from Six Dynasties to Song and Yuan period, they also turned into commercial centres. During the Ming and Qing Dynasties, they represented ongoing urban functional specialization, networked through waterways.

3. The Grand Canal integrated the South and North and promoted the birth and prosperity of cities, including their national unity. It had a major effect on promoting the Chinese political and economic development, as well as the cultural exchange because of the canals.

4. Three main urban tipping points characterized city models in the Yangtze Delta urbanization. Yangzhou was originally a military stronghold, but later became a regional turntable between the Yangtze River and the Grand Canal. Suzhou was a dominant economic centre in a prosperous region of a channel-building agricultural urban network, and Shanghai was a forerunner of Western domination.

The interactions between spatial form and the distribution of the water systems within these distinctive cities is the result of joint actions: operations of human power (political, institutional, infrastructural) and of non-human artefacts, such as the expanding waterways, climate, land, technology, historical events, and so forth. These three factors, actors, and institutions interplayed with each other, creating the urban morphology of the Yangtze River Metropolitan Delta. Nevertheless, they were also highly structurally motivated, top-down by the incentives and interests of the successive empires. Without them and the twentieth century Western colonial states, the Grand Canal system could never have played such a role in the urban history of this Delta (Figure 3). 


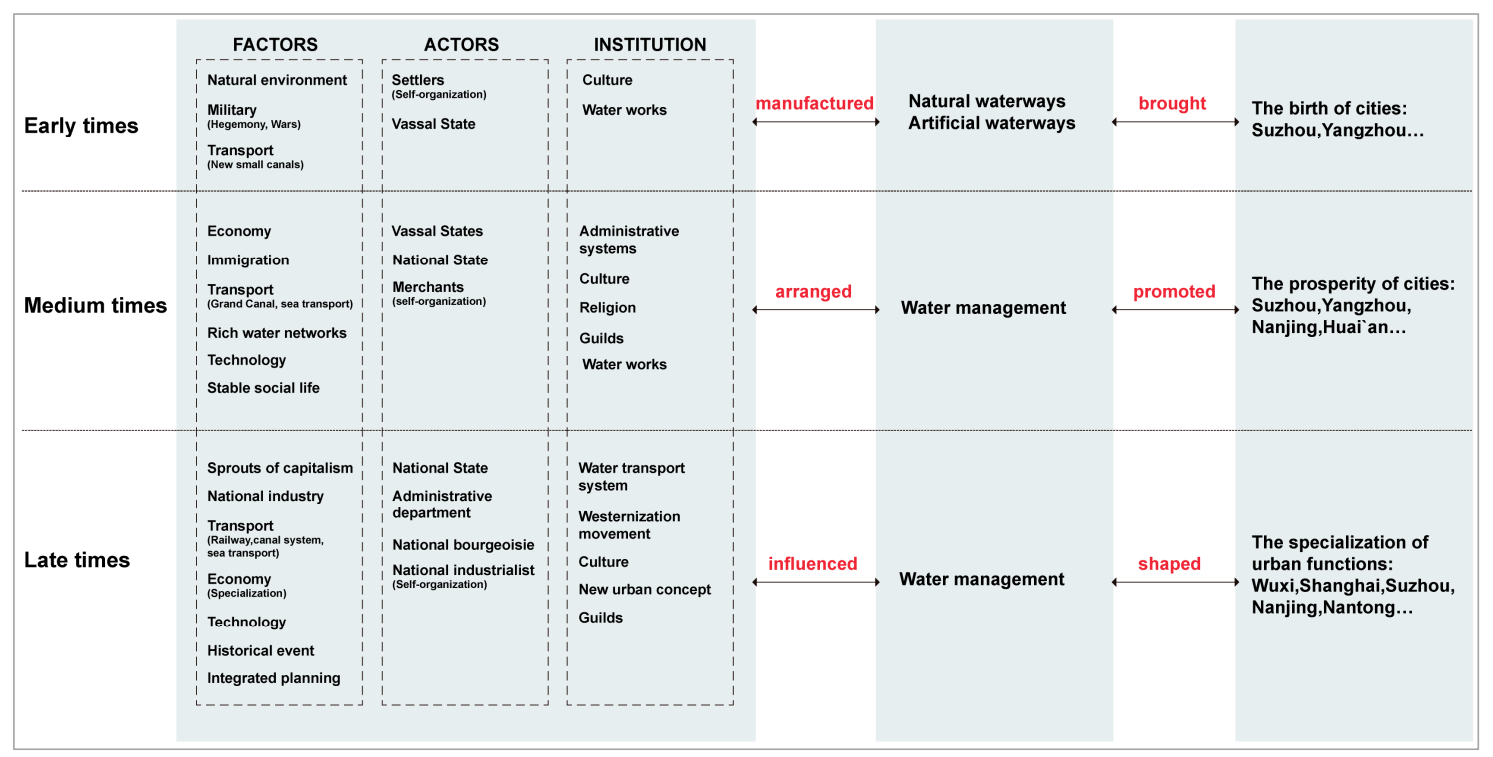

Figure 3. The Delta governance of Yangtze River Delta.

\section{The Euro Delta in Space and Time}

At first sight, the dynamic interchange of water management and urbanization within the Euro Delta seems to be completely different. Instead of the more than 23 centuries old empires and one political party reign in China-with the exception of brief periods of Charlemagne, Charles the 5th or the German occupancies in the First and Second World War-the Delta of Rhine, Meuse, and Scheldt (Euro Delta) has never been ruled by one big government. Even the Roman Limes (the border line of the Roman Empire) cut right through the Euro Delta during the first four centuries AD [11]. Moreover, this borderline was not even comparable with the Chinese Wall, built from the 7th century BC onwards, but served more or less as a highway or waterway between various strongholds, like the Grand Canal. Nevertheless, unlike its Chinese counterpart, it was highly adaptive to changing circumstances of climate, flooding, and mutable river courses [12]. In the aftermath of the Roman Empire, the Limes (meaning "path between building fields") served more or less as a transition zone between peoples on both sides of this so-called "borderline", and changed frequently, depending on morphological, political, or economic circumstances.

Thus, the history of hydrological urbanization in the Euro Delta reflects co-evolution with the volatile settings of its surroundings, rather than responding to specific decisions and/or major infrastructure developments from the top. From the Early Middle Ages in the Euro Delta, cities grew and shrunk, arose and fell into decay, or began almost literally to "walk", depending on the changing settings of tides and times [13]. New settlements appeared for a short period in the surroundings of old Roman or clerical urban fragments, only to disappear and subsequently reappear a bit further away. In this way, one of the first bottom-up trading places emerged in the Euro Delta: Dorestad. It reached a height of 4000 inhabitants, functioning for more than two centuries from the 7th century $\mathrm{AD}$ and beyond, in between the various reigns of the Franks, Saxons, and Frisians. It was a highly adaptive, early "small Delta-conurbation", adjusting its urban fabric according to the changing course of the Rhine, trading and negotiating between the surrounding regions, and temporarily retreating in the scraps of the Roman castellum nearby, when Vikings arrived to plunder the city [14].

This changed somewhat in the 10th and 11th centuries AD, especially in Flanders, the South-West section of the Euro Delta. A new ambitious district commissioner, Baldwin the First, started to rule this almost empty, regularly flooded, and therefore uncultivated land. At first, this was hardly noticed by the other rulers in the area, because of its impassibility. But especially during the second half of the 11th century, the climate warmed up remarkably, and thus, several marshes at the coast dried up in part [15]. 
Early Christian monasteries started to use this land for sheep breeding, which in turn, endangered the scarce vegetation, promoting the squirting of the small dunes, and thus, their protection against floods. To manage, the monks erected early ditches and dykes, damming the creeks. This attracted other slave farmers, still serving the noble men, but trying to improve their living conditions with additional income. By the end of the 11th century, more or less coherent coastal dike systems were elaborated, especially in the corner of a small stronghold, later known as Bruges. While these developments proved highly profitable for further cultivation and served a more or less steady, sweet water agricultural production; it was backed up by the new counts of Flanders. They started to attract the kind of project developer ("locators") among the lower noble men to mediate between the various pioneering farmers, in order to mutually develop dykes and drainage canals. At the same time, these "locators" tuned the developments with other water management initiatives, fishermen, and other interests in the surrounding area. Furthermore, after cultivation, they often served their ongoing mediating role in the management of these so-called "waterings". At first, the count appointed them as "dike earls" or "dike sheriffs", responsible for the sound and just management of those waterings. But later on, they were also periodically elected among the involved farmers themselves, as a kind of "primus inter pares". This institutional model of self-organization, with a certain degree of central justification, had two major advantages. First, the cultivation of flooded areas could be stimulated at very low cost, and with an accelerated pace, bottom-up. Second, one could enforce "free-riders" to co-operate, and mediate between communal conflicts, backed up by the law and order of the Flemish counts, if necessary. Thus, the agricultural production in the Bruges environs reached an unprecedented level, with respect to the previous infertile Euro Delta. It induced an upswing and prosperity of the city itself, which grew to some 50,000 inhabitants (the biggest in Western Europe at the time). However, in return, Bruges, with its good connections to the hinterland (the fertile grounds in northern France and Germany) and to the sea (England, Scandinavia, and even Italy) gave new impulses to the agricultural production in its environs, by selling its overproduction and promoting more profitable export products, such as flax and Flemish cloths [16]. This model was soon broadly copied, not only by the count of Flanders himself (in the regions of Veurne or Ghent), but also elsewhere, in the northern corners of the Euro Delta (like Zeeland and Holland), and even in other parts of Northwest Europe such as Bremen, Hamburg, and Danzig [15]. The organization and management of water systems in the urban fabric and its environments were highly interrelated, where waterways moved in and out of the city to nearby agricultural polders.

This "watering" or "polder model" also served organizational questions within other parts of the Delta society. When the first medieval cities appeared, they were regularly organized by the model of elected prominent civilians (in reference to the water system "schepenen") and a mayor appointed by the count. But later on, when cities gained more prominent economic and political status, these "primus inter pares" were (periodically) appointed by the local community itself.

To defend themselves against raids and robberies during travels, and to overcome the unpredictable whims and tolls of the numerous regional lords, merchants started to organise themselves according to different production sectors or trade routes in amecitia, friendships, or guilds. That was also the ground for the further elaboration of the merchant city network of the Hanze, operational for more than four centuries from the 14th century onwards, and which stretched at one moment from London/Bruges in the Southwest towards Novogorod in the Northeast, including more than 200 European cities [17].

Next, in the era of the global trade and colonisation from the 16th until the 19th centuries, the Oostendse, and West and East India Companies were loosely organised as a more or less bottom-up, self-organised, and open merchant city network, under the aegide of national governments. Unlike previously established counterparts elsewhere (e.g., the Company of Merchant Adventurers, or the Eastland and Levant Companies in London), these Euro Delta trading companies obtained the political and military power to act at these foreign shores on behalf of the governments in their motherland [18].

Other realms of urban life, such as the protestant religion, social housing, labour unions, financial and industrial corporations, and even political coalition strategies, were organised in the 19th and 
20th centuries according to this polder model of bottom-up self-organisation, and mutual cooperation under the protection and watchful eye of governments. This influenced Euro Delta urbanisation from various sides (Figures 4 and 5).

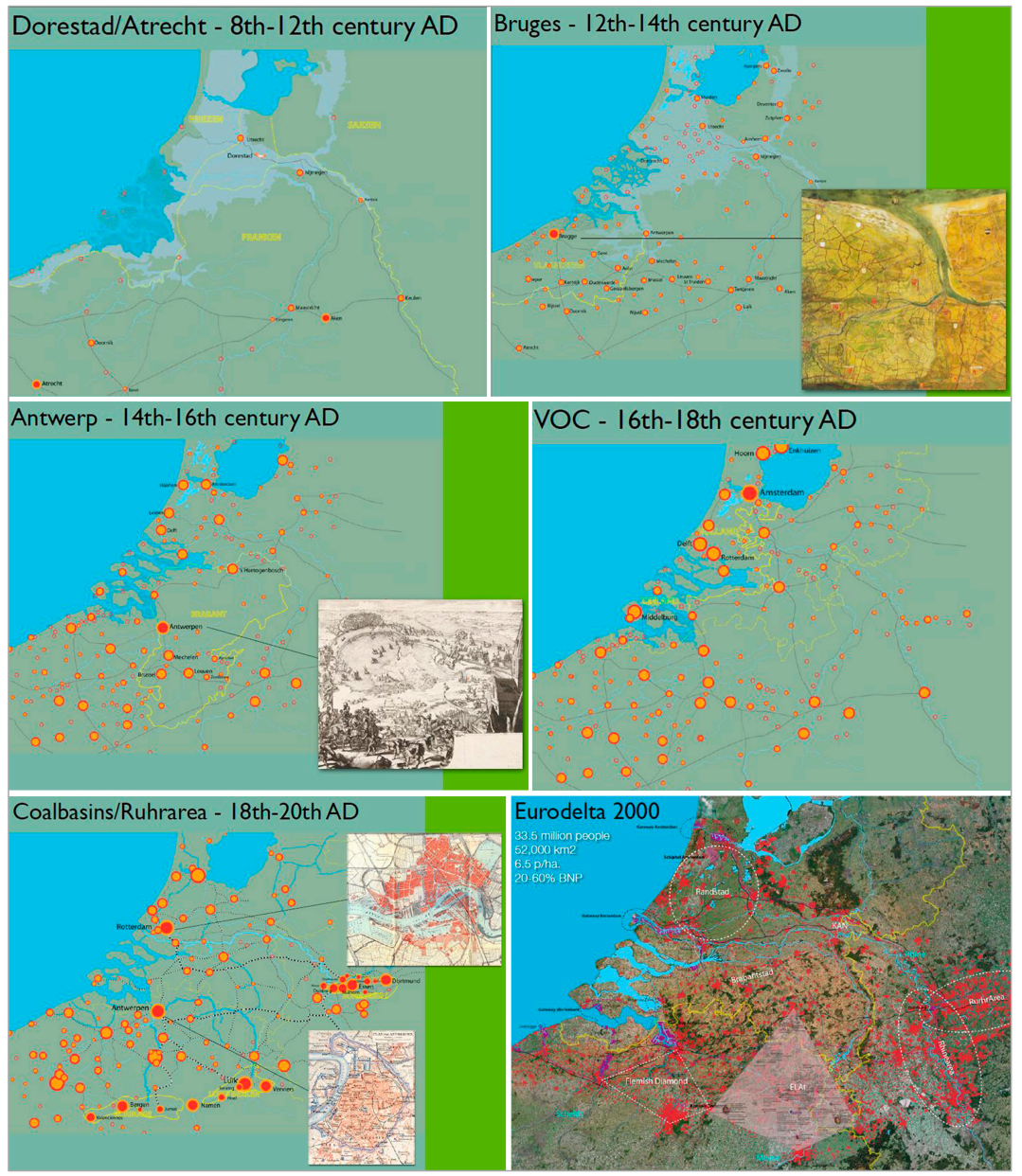

Figure 4. The urban morphology transformation of Euro Delta.

\begin{tabular}{|c|c|c|c|c|c|c|c|}
\hline Early times & $\begin{array}{l}\quad \text { FACTORS } \\
\text { Location } \\
\text { Military } \\
\text { Economy }\end{array}$ & $\begin{array}{l}\text { ACTORS } \\
\text { Traders } \\
\text { iself-organization) }\end{array}$ & $\begin{array}{l}\text { INSTITUTION } \\
\text { Liberty Conflict } \\
\text { Religion }\end{array}$ & manufactured & $\begin{array}{l}\text { Natural waterways } \\
\text { Artificial waterways }\end{array}$ & brought & $\begin{array}{l}\text { The birth of city groups: } \\
\text { Dorestad/Atrecht }\end{array}$ \\
\hline Medium times & $\begin{array}{l}\text { Waterings } \\
\text { Immigration } \\
\text { Transport } \\
\text { (Canals, sea transport) } \\
\text { Location } \\
\text { Technology } \\
\text { Economy }\end{array}$ & $\begin{array}{l}\text { Court of Flanders } \\
\text { Citizens } \\
\text { Farmers } \\
\text { Bankers } \\
\text { Merchants } \\
\text { self-roganization) } \\
\text { City holders }\end{array}$ & $\begin{array}{l}\text { Hanseatic League } \\
\text { City State } \\
\text { Religion } \\
\text { Church } \\
\text { Culture } \\
\text { voc wiC } \\
\text { Water works }\end{array}$ & arranged & Water management & promoted & $\begin{array}{l}\text { The prosperity of cities: } \\
\text { Bruges, Antwerp, } \\
\text { Amsterdam... }\end{array}$ \\
\hline Late times & 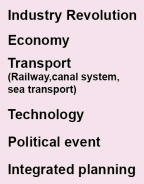 & $\begin{array}{l}\text { National State } \\
\text { Family bases } \\
\text { Technician, } \\
\text { Urban architect } \\
\text { ISel-organization) }\end{array}$ & $\begin{array}{l}\text { Nationism } \\
\text { Faculties } \\
\text { Culture } \\
\text { New urban concept } \\
\text { Works }\end{array}$ & influenced & Water management & shaped & $\begin{array}{l}\text { The specialization of } \\
\text { urban functions: } \\
\text { Rotterdam,Amsterdam, } \\
\text { Antwerp... }\end{array}$ \\
\hline
\end{tabular}

Figure 5. The Delta governance of Euro Delta. 


\section{Comparison between Two Deltas-Similarities and Differences}

The real and moral geography—as Simon Schama [19] called it—of the bottom-up, water-adaptive and "polder urbanised" Euro Delta seems to be completely different from the top-down, water infrastructure and authority-driven urbanisation of the Yangtze Delta. Nevertheless, there are some similarities. Next, we compare the similarities and differences between the two deltas from two aspects of urban morphology and urban governance.

\subsection{The Similarities and Differences in Urban Morphology}

\section{City site selection:}

From the urban physical space dimension, these two deltas were both distributed in the waterway-intensive areas, the selection of the city sites were nearby the watercourses, along branches of rivers, settling down at the higher areas, and more or less self-constructed within a humid environment. These factors determined, to a significant extent, where habitation was developed in the Euro and Yangtze River Deltas. An efficient water network, farmland, and high areas were three elements of the urban settlements' landscape of the Euro Delta, consistent with the early urban ideology of the city sites in China. The considerations of Chinese ancient settlement locations were topography, transport, and water. A famous ancient Chinese economist, philosopher, and politician Guan $\mathrm{Zi}$ wrote that in Spring and Autumn periods and warring states (475 BC-221 BC) "City Site selection should pay attention to the proper level of the terrain, neither too high nor too low ... this will not only eliminate construction of ditch defence, but also serve as a convenient water diversion" ("Guan Zi.Cheng Ma Di Wu").

\section{Urban form and urban elements:}

Influenced by different cultures, ancient philosophies and urban planning thoughts, there are obvious differences between the Yangtze River Delta and the Euro Delta in terms of urban form and urban elements. China's cities are mostly square, with regular layout and strong integrity. Imperial palace, Royal City, Drum Tower, official buildings, and so on, are located in the city centre, and occupy a large area. They are built on the main axis of the city, and the urban functions expand along the north-south axis. The road is a chessboard pattern, and the city is composed of city wall, city gate and moat. The Western cities are formed by spontaneity, forming an organic development of urban structure. Western European cities developed rapidly after the Middle Ages, mostly in ring and oval form. The size of the city is small. The city centre has a large square, where the church is located in. The market, the City Hall and the Belfry are distributed around the square. The square is a public place for the urban residents to buy and sell, to hold ceremonies, and so on. Around the market, there are various professional shops. The roads are radiated from the centre square to the surrounding. There are houses, shops, and handmade workshops on both sides of the streets. The cities of Western Europe are mainly developed on the three types of fortress, castles, and commercial traffic, and the cities with forts or castles are mostly composed of defensive walls, gates, and moats. The city form of the fortress presents a "Star" feature.

\section{The cores evolution and historical superposition of urban agglomeration:}

Due to changes in climate, water management, economic volatilities, and political hegemonies, the main urban focus points changed within both deltas throughout history. As the core urban regions switched in the Euro Delta from Dorestad / Atrecht (8th-12th century AD), Bruges (12th-14th century AD), Antwerp (14th-16th century AD), Amsterdam (16th-18th century AD), and the Coalbasins/Ruhrarea (18th-20th century AD), the same goes for the Yangtze Delta from Yangzhou in Tang Dynasty (618-907 AD), Suzhou in Song Dynasty (960-1279 AD), and Shanghai in the late Qing and Minguo Period (1840-1949 AD). The core of urban agglomeration has an alternate growth under the effect of the factors of urban management (factors, actors, and institution).

As a result, until the 20th century, both deltas would be characterised as vast urbanized areas of medium-sized urban cores. For ages, none of these urban cores exceeded their neighbours, but tried to specialize their own features to flourish. Recently, due to the colonial ambitions of Western states and specifically, due to neo-liberalization and the 1980s open door policies of the Chinese Communist 
Party, some urban nodes (like Shanghai) boomed to massive capital numbers. Overall, however, the formation of delta city groups still has features of these particular historical water-related origins. The location of the huge city groups is the concentration area of the ancient settlements and the city relics. The ancient relics and the modern cities' archipelagos present a remarkable additivity. These features of competition and collaboration (sometimes even at the same time) provide a certain historical basis for future urban challenges and planning management in metropolitan delta areas.

\subsection{The Similarities and Differences in Urban Governance}

From Figure 6, we could find out the similarities and differences of two delta governance directly. Factors, actors, and institution are three elements in metropolitan delta governance. In the early times of both delta urban development, location, natural environment, and military are the same factors that influence urban growing. However, the convenient transport that the new small canals built by vassal state was one significant factor in Chinese Yangtze River Delta in this period. Due to the different culture, under the influence of religion and liberty conflict, the economy played an important role in the Euro Delta at the beginning. Self-organization could be found in both areas, in the Yangtze River Delta, by settlers and vassal states, and in the Euro Delta counterpart, mostly by traders. In the mid-term of respective urban development, these two deltas were both affected by the factors of economy, immigration, transport (canals or sea transport, location, technology. Stable social life accelerated the rapid development of the Yangtze River Delta. Waterings played a vital role in Bruges' water management, and helped Bruges to its golden age. Regime/authority holders walked on the stage of history (vassal state, national state in the Yangtze River Delta and Court of Flanders, city holders in the Euro Delta). Meanwhile, as the economy developed, merchants self-organized the rational activities in both deltas. Citizens, farmers, and bankers paid high attention to the urban issues in the Bruges and Antwerp. Administrative systems (water administrative system in the Yangtze River Delta, Hanseatic League, VOC, WIC in the Euro Delta), culture, religion, and water works were the similar institutions that interplayed with factors and actors. In the late times of each urban development, industry revolution (expressed by national industry and sprouts of capitalism in China), economy, transport (railway, canal system, sea transport), technology, great events, and integrated planning were the analogous factors that influenced the expansion of modern cities together. National State determined the main issues in the countries. Simultaneously, self-organization could be found in both sides. Administrative departments, national bourgeoisie in the Yangtze River Delta, and family bases in the Euro Delta made the decision of some urban issues. Cultures and new urban concepts were influential in the motivation and determination of urban development. Water transport systems, westernization movements, guilds in China, nationalism, faculties, works in the Euro Delta, as the institutions interacted with other elements mentioned above (Figure 6).

\section{Factors:}

The Yangtze River Delta Metropolitan has mainly originated from military and political functions. The main reason for a "city" to be a "city", is to build walls, gates, and moats. With the development of the city, the urban economic function enters into the city, and the urban form is becoming more diversified. Therefore, the Yangtze River Delta Metropolis comes of political and military, and then the economic centre. The cities of the Euro Delta originate from the commercial links and trade between regions. Since seventh Century, the towns of Western Europe, which had administrative and religious functions, had begun to revive, and gradually grew into industrial and commercial centres. Different professional groups were gathered around the periphery of the castle and the monastery, and these areas had developed into a place for them to settle down and exchange products. In the late period of urban development, with the establishment of the state, the political function of the city was gradually highlighted. Therefore, the urban origin of the Euro Delta is mainly based on the economic and religious centres, and then, the political centre.

In view of the interaction factors of the water and the city in the two deltas, there are some common characteristics. The basic factors of the two deltas are all-natural elements, and the influence 
of climate, hydrology, and canal on urban form is huge. The fundamental factors are traffic factors, as the convenience of traffic brings economic development, and the urban network is built on the industrial chain, such as the Yangtze River Delta, developed from the canal era to the railway era. Bruges, Ghent, Antwerp, Rotterdam, and Amsterdam, during their golden ages in the Europe Delta, the convenient water and land transportation were the fundamental guarantee for the prosperity of the urban economy. The directly influencing factors are the military politics, military defence, war, and immigration, which directly influence the urban development and the form. The potential influencing factors are cultural factors. Religion, openness, and inclusion policies, innovation, and so forth, exert a subtle influence on the development of the two deltas.

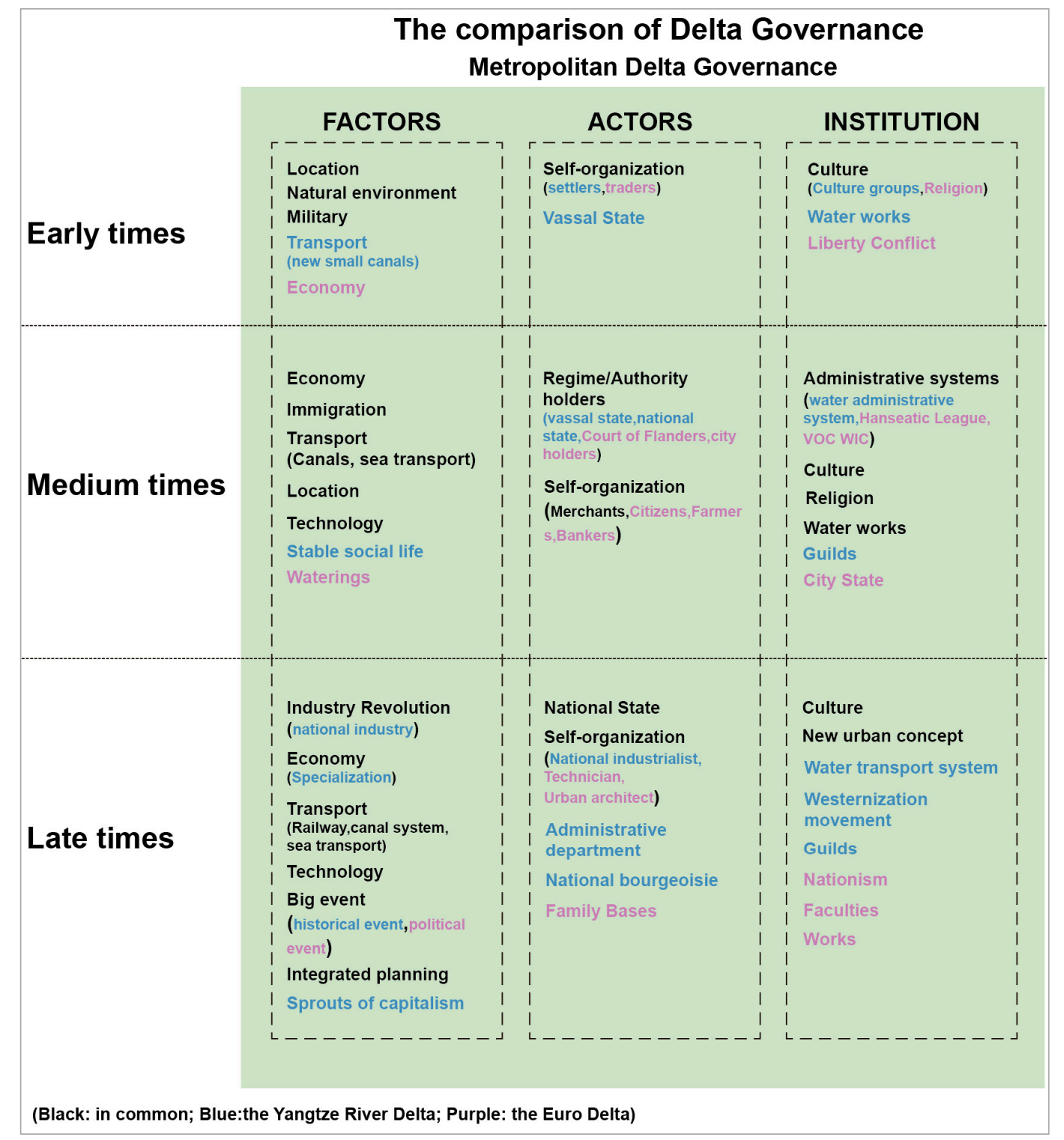

Figure 6. The comparison of Delta governance in Euro Delta and Yangtze River Delta.

The urbanisation in both deltas is also driven by civil-technical innovations in sustainable or resilient water management. As in Yangtze River Delta, canals had decided the contemporary urban pattern of the Jiangsu Province more than 2000 years ago; coast defence towns were growing up by defence systems along coastlines, from flooding. In the south of Jiangsu, numerous water towns and water countries were born within polders and paddy fields. Similarly as in the Euro Delta, the early 
coastal dike systems, the "locators", and the "waterings", made Bruges a stronghold. Amsterdam was founded in the late 12th century to the early 13th century, when a group of adventurers chose to settle down along the east bank of the Amstel downstream. Due to the low-lying settlements, they constructed a dam to protect inhabited settlements. The city grew via a system of canals, up into its golden age [20].

\section{Actors:}

The actors of a city refer to the leaders of urban behaviour. Their decisions and activities could directly determine the direction of urban development. The Western European cities in the Middle Ages were mainly developed by economy, and engaged in industrial and commercial activities. The main actors of the city were the independent operators, such as handicraftsmen and businessmen. China's ancient cities mostly originated from the political and military centre, and the city structure was also more complex, and the main actors in the feudal society were mainly the ruling class and nobles, while the people who engaged in commercial activities had less discourse power, and were in subordinate position.

Through time and in both regions, merchants played a significant role in delta governance. This was seen through a two-tier system of the Court of Flanders and city holders in the Euro Delta, and the vassal state and national state in Yangtze River Delta. They constructed commercial consultations or guilds in the cities to protect their own interests, contributing to the urban development and architecture landscape. The water administrative systems and economic administrative systems impacted their decision. But China's guilds were different from those in Western Europe. With the progress of technology and society, the economic functions of Chinese cities were playing an increasingly important social role. Businessmen were frequently active in the development of urban trade and economy. The guild organizations, which were developed by region and kinship, had begun to protect their interests. "China's guilds will pay taxes to the government and manage the guilds with the authority of the government" [21]. These guild organizations were generally highly mobile, and still belonged to feudalism. They participated in urban activities, but it was hard to form an independent class and fully grasp the dominant power of cities. In the European Delta cities, businessmen were respected, and enjoyed high legal status. There were special commercial laws to protect the interests of merchants, and some prominent families were also engaged in industrial and commercial activities. "The merchant of Western European cities is not only a person of freedom of identity, but also a person who enjoys the privileges of commercial law in the market" [22].

\section{Institutions:}

The urban institution of the Euro delta is reflected as a bottom-up management system, while China's counterpart is dominated by top-down. But, in the Chinese Yangtze River Delta, bottom-up organizations can be found. Chinese self-organization started late. It was embodied in the presence of the guilds from the Ming Dynasty (1368-1644 AD), the family manual mills in Ming and Qing Dynasty (1368-1911 AD), and national industry in the late Qing and Minguo Periods (1840-1949 AD). Even in Shanghai, before the French and English occupation, merchants established so-called huiguan or gangsuo, based on their region or trade, geographically or functionally [23]. These guilds flourished within the same hometown or the same and relational trade. This kind of organization began with the early Ming Dynasty, and achieved prosperity in the Qing Dynasty. Under these conditions, some guilds played a major role in protecting sectors' own interests, like the Hanze did in the Euro Delta. But often, those guilds were restricted to their home base, and hardly stretched beyond the regional frontiers towards other inter-regional urban networks. Throughout history, the successive Chinese emperors were expected to be responsible for cross-regional networks, their safety, as well as maintaining a level playing field. As a result, their guilds were much less differentiated, when compared to co-evolutionary and relational innovations in their European counterparts. At the end of the 19th century, Shanghai began to flourish again through the international networks, under European influence.

In the Euro Delta, top-down organizations also can be found. From the second half of 18th century, the government paid more attention to water management, manifested in the establishment of water 
management organizations and the assignment of treaties about water. Christiaan Brunings (1736-1850) took charge of the Bureau of Water, and signed a treaty about the distribution of the Rhine water, presenting the first step towards international consultation about matters of water [20]. The Ministry of Water Management and Public Works was set up in the year of 1815, the power of the district water boards was restored in 1817, the Royal Institute of Engineers was established during the period of 1847, and in 1872, the Directorate of River Control was found. In the age of 20th century, the Dutch had developed the Delta Plan for defending the flood (after the flood in 1953). "The combination of tidal calculations and electro-hydraulic models provides an insight into the current changes in the tidal rivers as a result of the execution of the Delta Plan" [20].

In spite of the national actions mentioned above; until mid-20th century, there were still some 2500 waterboards active in the Netherlands; and until today, still active in Flanders. In general, however, as the technology and the development of the society progressed, the cities' development was related to a complex co-evolution of urban layout and water management. While history of the interaction between water management and urban development in the Euro Delta shows a kind of bottom-up organization, the history of the Yangtze River Delta mostly presents a kind of top-down construction. Therefore, the nexus and connection between urbanization and water takes on different characteristics. Where the Euro Delta presents some kind of marine culture, due to the fluctuating and regularly flooded coastline, the Yangtze River Delta presents a kind of river and Grand Canal culture, and from the cities, there emerged nearby rivers and canals in the vast, deep hinterland, reflecting the typical features of introversion, and relative geographic and political stability.

\section{Learning about Future Challenges}

To become more resilient with respect to the climate and water challenges ahead (including flooding and scarcity of water), the urbanization in both delta areas could learn from each other. The Euro Delta may need an overall strategy and integrated investments in civil-technical works through territorial differences, governments, and centuries, like the Chinese Grand Canal in ancient time and modern "high-speed railway" plus "cities network" (including internet network, transport network, life systems, etc.) with its adjoining urbanization, within an integrated political framework.

The current Yangtze River Delta is already the most dynamic and innovative city group in China, including three provincial capital cities, Nanjing, Hangzhou, and Hefei. Around the Chinese top economic representative Shanghai City, there have been Hangzhou, Ningbo, Suzhou, Wuxi, Nanjing and a number of such new first-tier cities. This area has 150 million of China's population, but only accounts for $2.1 \%$ of national area, and comprises one-quarter of the national economy. These are all inseparable from the integration of the overall strategies and planning. In the historical period, the construction of the Grand Canal experienced various periods and dynasties is the embodiment of the overall strategic deployment, and planning of the ancient water management project. The integrated traffic network, economic network, and life network, forming a network pattern of urbanization, was closely connected with the water system. In the contemporary era, a series of strategic plans related to the Yangtze River Delta and the economic belt of the Yangtze River, have contributed to the development of this region. In May 2016, for instance, the Chinese government approved the "City Cluster Plan for Yangtze River Delta", in order to foster a higher level of economic growth pole. The Yangtze River Delta urban agglomerations, with Shanghai as the core, closely link to the composition of a number of cities, and the planning includes twenty-six cities from Jiansu, Zhejiang, and Anhui Province, covering an area of 211,700 square kilometres. The planning made the goals for urban functions, the construction of integrated transport and economic development within the region, which is bound to promote the urban development. In September of 2014, the Chinese government issued "the guidance of the State Council on the promotion of the development of the Yangtze Economic Belt on the basis of the golden waterway". It is pointed out that this relies on the golden channel to promote the development of the economic belt of the Yangtze River and to build a new support zone for China's economy. It should also build comprehensive three-dimensional transportation corridors; the innovate drive promotes 
industrial transformation and upgrading, and it provides guidance for optimizing the urbanization pattern along the Yangtze River and enhancing the international competitiveness of Yangtze River Delta urban agglomerations.

Shanghai Free Trade Zone, Zhejiang Free Trade Zone, Zhangjiang National Science Centre, Hefei National Science Centre, Sunan National Innovation Park and so on, are based on the national strategy, and the Yangtze River Delta region is steadily moving towards a world-class city group with global influence. Relying on the overall strategies and plans, the Yangtze River Delta is stepping into a new stage of comprehensive coordination and integration. The development of the metropolitan area is breaking through the boundary of the administrative region, and the 26 cities, with Shanghai as the leading city, are gradually realizing urban integration. This kind of urbanization is embodied in traffic, internet, industry, science and technology, service, and so on. Some new cities that have been incorporated into the Yangtze River Delta have benefited a lot. As like the capital city of Anhui Province, Hefei is absorbing advanced science and technology from the coastal areas, while the comprehensive national science centre is being built. Under the guidance of the policy, the urban plans and policies involve frequent interaction, and each city will have a broader space.

The interactive development of water and city in the Yangtze River Delta metropolitan area has gone through the agricultural and industrial times, and now it is experiencing the post-industrialization era. The agricultural era relied on water systems for industrial agglomeration, and the ancient urban and rural settlement space had sprung up along the water system. At this stage, the water system was the key factor for the development of cities and towns. The Yangtze River Delta Basin was the birthplace of the Chinese national capitalist industry in modern times. In the age of industrialization, the mode of industrial agglomeration relied on roads and railways. The rise of transportation hub cities had gradually formed towns network system connected by highways and railways. The development of land traffic made the status of water transport decline gradually. At present, the Yangtze River Delta Basin has been entered, and it is experiencing the post-industrial era. The construction of high speed railway makes it possible to commute in different places. It forms a new urban network pattern of high-speed road and railway networks, and the urban network space links are strengthened, and has virtually grown into a highly integrated mega metropolis belt. The high-speed rail blurs the boundaries of the urban agglomeration, as it takes just two hours from one city group to another along the Beijing-Shanghai high-speed railway and Beijing-Guangzhou high-speed railway. Many urban agglomerations constitute the national scale urban network.

The Yangtze River Delta cities could learn from the Euro Delta cities how to deal with water resilient landscape historically. That is, not to isolate history, and allow historical resources to continue to fulfil their own value in contemporary development, promoting urban development better. Bruges, the whole city including its world cultural heritage, its water environment as the linear historical context, and important parts of the historical landscape, with landmark historical buildings and rich human activities, forms successional and operational historical landscapes. About the planning and design of waterfront areas, the Euro Delta cities advise the urban constructions to face the water, retain historical memories, and combine with modern planning and human activities, in line with urban ecological development requirements in realising "resilient" development, as seen in the renovation of Het Eilandje (dock areas) in Antwerp, Kinderdijk in Rotterdam.

The Yangtze River Delta cities could also learn from the successful European experience in different projects in water management to solve a city's practical problems. For example, in the practical application of the idea "space for the rivers", the water garages and water squares could be in the use in Chinese Sponge City. The Yangtze Delta may need more local, embedded, but networked approaches, to become more adaptive to unpredictable and changing circumstances.

In the polycentric metropolitan deltas, more than in the vast mono-centric capital metropoles, urban morphology is the embodiment of geographic physical dimensions, interplayed with major actors and stakeholders from the public, business, and civic communities. From there, and throughout time, specific delta institutional urban water settings evolve, including laws, culture, norms, religion, 
and so on, which in turn, condition the co-evolution of the leading actors and volatile factors in deltas. In this process, nature, economy, transport, population, technology, society, culture, opportunities, and numerous dynamic mechanisms co-evolve among each other. Delta management must be concerned with this continuous interplay in order to survive, especially in times of climate change.

Acknowledgments: China Scholarship Council. China Scholarship Council provided the funding of one year's study at Ghent University for the research of the Euro Delta.

Author Contributions: Yan Wang conceived, designed and wrote the paper, and drew the Figures 1-3, 5 and 6; Wei Dong offered the proposals and comments for the paper; Luuk Boelens wrote some part of the paper, gave comments for the paper and drew Figure 4.

Conflicts of Interest: The authors declare no conflict of interest.

\section{References}

1. Zou, H.; Yang, J. Dynamic Relationship between Evolvement of City Form and City Water System. Planners 2003, 19, 87-90.

2. Boelens, L.; Taverne, E. Why Cities Prosper as Deltas: The Urbanisation of the Eurodelta. In Living in the City: Urban Institutions in the Low Countries, 1200-2010; Lucassen, L.L., Willems, W.W., Eds.; Routledge: New York, NY, USA, 2012; pp. 192-215. ISBN 9780415893787.

3. "Yangtze (Yangzi, Changjiang) River Delta". China Today. Available online: http:/ /www.chinatoday.com/ city / china_yangtze_river_delta.htm (accessed on 27 March 2013).

4. Fu, C. The History of Chinese Canal Cities Development; Sichuan People's Publishing House: Chengdu, China, 1985; ISBN 11118-179.

5. Boelens, L. Delta Governance: The DNA of a Specific Kind of Urbanization. Built Environ. 2014, 40, 169-183. [CrossRef]

6. Boelens, L. Moving towards a flat ontology of institutional innovation: Actor-relational lessons learned from early water management perspectives. Routledge 2018, accepted.

7. Fan, Y. On the Development of Rice Farming in Tai Lake Area during the Neolithic Age of China. Master's Thesis, Nanjing Agricultural University, Nanjing, China, 2011.

8. Fu, C. The History of Grand Canal; Social Sciences Academic Press: Beijing, China, 2011; ISBN 9787509725160.

9. Yao, X. Information on the History of Foreign Trade in Modern China-Book One; Zhong Hua Book Company: Beijing, China, 1962; p. 556.

10. Ling, S. Huanghe River Captured Huaihe River and Agricultural Settlement in North Jiangsu Coastal Area in the Historical Periods. J. Anhui Agric. Sci. 2009, 37, 7253-7254.

11. Colenbrander, B. (Ed.) Limes Atlas; 010 Publishers: Rotterdam, The Netherlands, 2005; ISBN 9064505357.

12. Bloemers, T. Een Eerste Stap Naar Stedelijkheid in de Rijndelta. In Limes Atlas; Colenbrander, B., Ed.; 010 Publishers: Rotterdam, The Netherlands, 2005; pp. 21-26. ISBN 9064505357.

13. Taverne, E.; naar Dorestad, T. Op zoek naar stedelijke stelsels in de noordelijke delta. In Stadswording in de Nederlanden: Op Zoek naar Overzicht; Rutte, R., Engen, H., Eds.; Verloren: Hilversum, The Netherlands, 2005; pp. 171-186. ISBN 906550849X.

14. Willemsen, A. Dorestad. Een Wereldstad in de Middeleeuwen; Walburg Pers: Zutphen, The Netherlands, 2009; ISBN 9789057306273.

15. Prak, M.; van Zanden, L. (Eds.) Nederland en Het Poldermodel. Sociaal-Economische Geschiedenis van Nederland, 1000-2000; Bert Bakker: Amsterdam, The Netherlands, 2013.

16. Blockmans, W. Metropolen aan de Noordzee. De Geschiedenis van Nederland, 1100-1560; Bert Bakker: Amsterdam, The Netherlands, 2010; ISBN 9789035127753.

17. D'Haenesns, A. De Wereld van de Hanze; Mercatorfonds: Antwerpen, Belgium, 1984; ISBN 9061531292.

18. Prince, G. De commerciële revolutie en het wereldsysteem. In Veelvormige Dynamiek. Europa in Het Ancien Régime, 1450-1800; Frijhoff, W., Wessels, L., Eds.; SUN: Amsterdam, The Netherlands, 2006.

19. Schama, S.; Overvloed en Onbehagen. De Nederlandse Cultuur in de Gouden Eeuw; Contact: Amsterdam, The Netherlands, 1987; ISBN 9025466095.

20. Hooimeijer, F.; Meyer, H.; Nienhuis, A. Atlas of Dutch Water Cities; Sun Architecture: Amsterdam, The Netherlands, 2005; ISBN 9789058751744. 
21. Chang, T. The comparison of Ancient Chinese and Western cities. CO-Oerativeconomy Sci. 2017, 2, 48-49.

22. Li, Y. Comparative study on the differences between Chinese and Western feudal cities. J. Anhui Univ. 2005, 29, 104-107.

23. Denison, E.; Ren, G.Y. Building Shanghai: The Story of China's Gateway; Wiley-Academy: Chichester, UK; Hoboken, NJ, USA, 2006; ISBN 9780470016374. 